\title{
Adaptarea formală a toponimelor în traduceri românești cu original german din perioada $1780-1830^{\dagger}$
}

\author{
Ana-Maria Gînsac, Mădălina Ungureanu* \\ Departamentul de Cercetare Interdisciplinar - Domeniul Socio-Uman, Universitatea „Alexandru Ioan Cuza”, \\ Str. Lascăr Catargi 54, 700107 Iaşi, România
}

\section{Despre articol \\ Istoric:}

Primit 2 februarie 2018

Acceptat 13 februarie 2018

Publicat 27 aprilie 2018

Cuvinte-cheie:

contact lingvistic

onomastică

toponimie

traducere

scriere laică

\begin{abstract}
Rezumat
Deși problema transpunerii numelor proprii străine în limba română dinaintea epocii moderne este insuficient studiată, este cunoscut faptul că procesul se caracterizează (ca întregul scris românesc al epocii) prin lipsa unor norme general valabile care să îl reglementeze. Transpunerea numelor proprii străine în limba română este influențată de diverși factori, între care: existența unor alfabete și a unor sisteme ortografice și fonetice diferite; influența modelului lingvistic al textului-sursă vs. existența unor modele tradiționale de pronunțare; preluarea numelor proprii prin diverse filiere lingvistice (franceză, germană, italiană etc.); conținutul divers de nume proprii al textelor; pregătirea lingvistică a traducătorilor. Ne propunem să discutăm, din perspectiva strategiilor de traducere, problema adaptării formale a toponimelor din trei texte cu conținut istoric traduse în limba română din limba germană în perioada 1780-1830.
\end{abstract}

\section{Introducere}

Considerată drept prima etapă din „epoca modernă” a istoriei limbii române literare sau o etapă „de tranziție” între vechea română literară și româna literară modernă (Gheție, 1982, p. 65; Munteanu \& Țâra, 1983, p. 169, 176), numită și „epoca premodernă” (Piru, 1970, p. 5, cu referire la etapa de tranziție dintre literatura veche și cea modernă), perioada anilor 1780-1830/40 reprezintă începutul modernizării limbii române prin traducerea unor texte din diverse domenii ale culturii scrise (religios, filozofic, istoric, geografic, literar etc.) și din diferite limbi moderne (franceză, germană, italiană, rusă etc.). Un rol hotărîtor în „direcționarea” procesului de modernizare a limbii române literare l-au avut reprezentanții Școlii Ardelene, care au alcătuit o serie de lucrări normative (gramatici, ortografii, lexicoane), au tradus tratate științifice și juridico-administrative, precum și numeroase lucrări beletristice, edificînd astfel „principalele deziderate ale normării și modernizării limbii române literare” (Gheție, 1982, p. 75). Numeroasele traduceri românești din această perioadă au fost puțin cercetate din perspectiva procesului de transpunere a textului dintr-o limbă străină în limba română. În acest context, ne propunem să urmărim modul în care au fost adaptate formal (grafic, fonetic și morfologic) în limba română numele proprii din cîteva traduceri ale unor lucrări scrise în limba germană. Este vorba despre trei texte cu conţinut istoric, pe care le prezentăm sintetic:

a) Descoperirea Américii. O carte foarte folositoare (= Cam.rom.), apărută la Buda, în 1816, sub îngrijirea editorială a lui Nicola Nicolau, este traducerea în limba română a primului volum al lucrării Kolumbus oder die Entdekkung von Westindien. Ein angenehmes und nützliches Lesebuch für Kinder und junge Leute de Joachim Heinrich Campe; este prezentată istoria descoperirii Americii, povestită

${ }^{\dagger}$ Acknowledgment: Acest articol a fost publicat în cadrul proiectului Practici de traducere a numelor proprii în scrisul românesc premodern: 1780-1830 (PN-II-RU-TE-2014-4-1108), finanțat de Unitatea Executivă pentru Finanțarea Învățământului Superior, a Cercetării, Dezvoltării și Inovării din România (CNCS-UEFISCDI).

*Adrese de corespondență:anamaria.gansac@gmail.com(AMG),madandronic@gmail.com(MU). 
de un tată copiilor săi, sub formă de dialoguri; în urma comparării edițiilor în limba germană, am luat ca text de referință ediţia publicată la Tübingen, în $1782(=\text { Cam.germ. })^{1}$;

b) manualul de istorie Élémens d'histoire générale al abatelui Claude-François-Xavier Millot, apărut la Paris începînd cu anul 1772 (în nouă volume), a fost tradus în limba română de Ioan Molnar-Piuariu și publicat la Buda, în 1800, cu titlul Istoria universală (= Mil.rom.); traducătorul a folosit ca sursă principală versiunea în limba germană a lucrării, Universalhistorie alter mittler und neuer Zeiten, din 1794 (= Mil.germ.), datorată lui Wilhelm Ernst Christiani²;

c) lucrarea Alexander I, Kaiser von Russland. Ein Regierungs- und Karaktergemälde (Berlin, 1814) a lui Johann Daniel Friedrich Rumpf (=Rum. germ.) a fost publicată, la fel ca alte portrete laudative ale țarului Alexandru I al Rusiei, cu scopul de a contracara mitul napoleonian și pentru a ridica prestigiul adversarului împăratului francez; traducerea în limba română a acesteia, Arătarea stăpînirei și a caracterului lui Alexandru I, împăratul a toată Rossia (= Rum.rom.), a apărut la Buda, în 1815, fără ca numele traducătorului să fie menționat ${ }^{3}$.

Textele amintite mai sus conțin diferite tipuri de nume de locuri (toponime): hidronime (nume proprii de oceane, mări, lacuri, fluvii, rîuri), horonime (nume proprii de continente, țări, subdiviziuni administrative, regiuni, provincii), oiconime (nume proprii de habitate: oraşe, cetăţi-stat), oronime (nume proprii de munți sau dealuri) și nesonime (nume proprii de insule). Pornind de la procedeele de traducere adoptate de traducători, ne propunem să urmărim modul în care au fost adaptate la specificul formal al limbii române toponimele din textele menționate.

\section{Dificultăţi ale adaptării formale a numelor proprii în limba română, în perioada premodernă}

Deși problema adaptării numelor proprii în limba română dinaintea epocii moderne este insuficient studiată, este îndeobște cunoscut faptul că procesul se caracterizează (ca întregul scris românesc al epocii) prin lipsa unor norme general valabile care să reglementeze acest transfer ${ }^{4}$. În lipsa acestor norme $e^{5}$, oscilațiile în adaptarea numelor proprii sînt determinate de factori pe care îi detaliem mai jos.

a) Utilizarea unor alfabete diferite

Sursele traducerilor care au furnizat corpusul numelor proprii supus studiului sînt scrise cu alfabet latin. În epocă, limba română era scrisă preponderent cu alfabet chirilic. Este vorba, aşadar, despre două sisteme grafice diferite: număr diferit de grafeme, semne diacritice specifice (cu sau fără valoare fonetică), existența unor grafeme cu valori fonetice multiple sau, dimpotrivă, a unor grafeme sau grupuri de grafeme care notează aceeași secvență fonetică. Confruntarea celor două sisteme grafice implică, pentru traducător, dificultăți în alegerea modalităţii de transpunere a numelor proprii în limba română.

b) Sisteme ortografice diferite

Limbile aflate în contact în procesul de traducere a textelor care formează baza studiului nostru au ortografii bazate pe principii diferite: ortografia germană manifestă tendințe etimologizante, în timp ce ortografia româno-chirilică este una fonetică.

În ceea ce privește principiul care stătea la baza ortografiei românești, părerile specialiștilor sînt împărțite. Opinia devenită clasică este aceea că ortografia româno-chirilică este una fonetică: „Apli-

\footnotetext{
${ }^{1}$ Traducătorul nu este menționat.

${ }^{2}$ Despre sursa traducerii, vezi Grămadă (1960, p. 166), Ursu (2002) și Minuț \& Lihaciu (2014).

${ }^{3} \mathrm{Cu}$ privire la această traducere, vezi Cernovodeanu (1974).

${ }^{4}$ Folosim termenii transpunere, transfer și traducere în sens larg: trecerea unui semn lingvistic dintr-o limbă în alta; specificăm de fiecare dată procedeele/strategiile de traducere întîlnite în textele studiate ( $\mathrm{r}$ r a n s li t e r a r e, tra n s c ri e r e etc.).

${ }^{5}$ Lipsa unor norme clare de redare a numelor proprii străine în limba română caracterizează și epoca modernă; vezi Ștefănescu (1957), Bârsan (1961), Bolocan (1961), Theban (1965). Pentru transpunerea numelor din limbile clasice propun sisteme Creția (1958) și Costa (1958); în privința acestora din urmă, uzul nu este unitar nici astăzi.
} 
carea alfabetului chirilic în scrierea limbii române, încă înainte de secolul al XVI-lea și pînă la jumătatea secolului trecut, nu s-a efectuat în virtutea unor norme ortografice fixate în scris, care să fi fost obligatorii pentru toți mînuitorii condeiului, așa încît aceștia-scriind-se lăsau conduși de fonetismul pe care îl deprinseseră în vorbirea limbii; aşa se explică și faptul [...] că s-a aplicat ortografia fonetică (s.a.) de la începuturile scrisului în limba română” (Strungaru, 1976, p. 197). În acest sens, Stan (2012, p. 7) consideră simptomatic faptul că, în Lexiconul de la Buda (1825), notaţiile cu alfabet chirilic aveau rolul de a indica rostirea; așadar, cele cu alfabet latin reprezentau opțiunea etimologizantă a ardelenilor, în timp ce cele cu caractere chirilice indicau cititorului fonetismul cuvîntului respectiv. Dimpotrivă, Boerescu (2014, p. 88) afirmă despre grafia chirilică tradițională românească că „este, de la începuturi și pînă aproape de 1830 [...], o scriere bazată exclusiv pe tradiția slavonă și pe etimologismul cultural grec, cu insuficiente adaptări la fonetica limbii române”, opinie pe care o opune celei a lui Strungaru (1976), exprimată mai sus; impresia de scriere „fonetică” ar veni din regularizarea de după 1750 . Susținînd ideea că ortografia româno-chirilică era tradițională și etimologică, Boerescu (2014, p. 88) se sprijină pe Gheție \& Mareș (1985, p. 153-164), care arată că slovele sînt utilizate, în primele texte românești, cu valorile pe care le aveau în scrierea mediobulgară; autorii citați fac diferența, însă, între scrierile religioase, cu această caracteristică, și documentele epocii, caracterizate printr-o ortografie simplificatoare și o tendință de renunțare la întrebuințări convenționale (Gheție \& Mareș, 1985, p. 161), deci care merg spre o ortografie mai degrabă fonetică (deși componenta tradițională nu lipsește); cu atît mai mult este acest lucru valabil cu două secole mai tîrziu, și mai ales în textele laice. În opinia noastră, autorul exagerează caracterul etimologic: acesta nu poate fi raportat decît la cuvintele provenite din slavonă şi greacă, nu şi la cuvintele moștenite sau la cele de origine slavă, a căror notaţie este fonetică, desigur, cu o componentă tradițională puternică. Atunci cînd notează un cuvînt cu caractere chirilice, scribul nu intenționează să obțină o formă cît mai apropiată de cea a etimonului, ci încearcă să-i reproducă pronunția, între limitele regulilor sistemului grafic pe care îl folosește, cu componentele sale tradiționale. Ideea că ar exista o diferență fundamentală între ortografia dinainte și cea de după 1750 este infirmată chiar de textele care constituie suportul studiului de faţă; întîlnim și aici slove cu valori multiple, slove și semne diacritice fără valoare fonetică, dublete grafice. Desigur că, de la primele scrieri în limba română din secolul al XVI-lea și pînă la mijlocul secolului al XVIII-lea, ortografia a evoluat în sensul simplificării unora dintre reguli, mai ales în direcția specializării slovelor; după cum arată, însă, textele de față, această evoluție nu este semnificativă. De asemenea, sîntem de acord cu ideea că bigrafismul din Lexiconul de la Buda (1825) arată principiile diferite pe care se sprijină cele două ortografii în epocă, cea chirilică și cea cu alfabet latin.

c) Sisteme fonetice diferite

Fiecare limbă este caracterizată prin prezența unor foneme inexistente în alte limbi, de unde necesitatea ca ele să fie aproximate în limba-țintă. Astfel de foneme sînt, de pildă, în limba cu care româna intră în contact în traducerile studiate, vocala anterioară închisă rotunjită /y/ (reprezentată grafic în germană ca $\ddot{u}$ ), vocala anterioară deschisă rotunjită /œ/ (reprezentată grafic în germană ca $\ddot{o}$ sau $o e$ ).

d) Diversitatea numelor proprii prezente în texte

Traducerile din această perioadă se referă, de multe ori, la realităţi inedite pentru cultura română a epocii (spații exotice): Cam.rom. vorbește despre America de Sud și de Nord; Mil. rom. este o istorie universală; Rum.rom. prezintă aspecte din istoria, geografia și politica Imperiului Rus. Unele dintre realitățile conținute în aceste lucrări și numele lor îi erau, firește, cunoscute traducătorului și chiar cititorilor pe care acesta îi avea în vedere; altele, însă, erau necunoscute: traducătorul nu le poate raporta la vreun sistem cunoscut. În cele mai multe cazuri, realităţile despre care vorbește o lucrare sînt exterioare sferei sale lingvistice. Se poate întîmpla, aşadar, ca traducătorul să încerce să redea nu grafia sau pronunția din limba-sursă (pentru care numele respectiv este exonim), ci pronunția pe care o cunoaște sau o presupune în limba care corespunde universului la care face referire textul.

e) Existența unor modele tradiționale de pronunțare (pentru numele foarte cunoscute) 
Acest lucru limitează posibilitatea inovațiilor din partea traducătorului. Este ceea ce observă și Garde (1974, p. 4) cînd vorbește despre transcrierea numelor franțuzești în limba rusă contemporană: există un conflict între numele proprii lipsite de notorietate, necunoscute, care pot fi supuse unei transcrieri după principii unitare, și cele foarte cunoscute, care au deja o tradiție grafică și/sau fonetică în limba-țintă și care trebuie păstrate conform acesteia.

\section{Adaptarea grafică și fonetică. Procedee de traducere}

\subsection{Imprumutul}

Împrumutul constă în preluarea numelui propriu cu forma grafică şi morfologică din limba-sursă. Ballard (2011, p. 26) numește acest procedeu report și îl definește ca „transferul integral al numelui propriu din textul-sursă în textul-țintă”, „gradul zero al traducerii semnificantului”, deși mai departe susține că și transliterarea şi transcrierea sînt tot procedee de report (Ballard, 2011, p. 42).

În cazul Cam.rom., se manifestă uneori un interesant caz de „bigrafism monolingvistic”; sintagma îi aparține lui Boerescu (2014, p. 87), care o folosește pentru a defini coexistența alfabetelor chirilic și latin pentru notarea limbii române în perioada 1780-1880. Am preluat-o aici pentru a defini situațiile, specifice numai acestui text, în care autorul, transcriind un nume propriu din textul german, îl reproduce în ambele alfabete. Există trei tipuri de situații, pe care le vom detalia mai jos. În grupajul (1), numele proprii din original sînt reproduse numai cu alfabet latin:

(1) Dominika (Cam.germ., 132) - Dominica (Cam.rom., 78), Mari galante (Cam.germ., 133) - Maria galante (Cam.rom., 78), Guadalupe (Cam.germ., 133) - Kuadelupe (Cam.rom., 78), Antigua (Cam.germ., 133) - Antiqua (Cam.rom., 78),

Portoriko (Cam.germ., 133) - Porto Rico (Cam.rom., 78), die Insel St. Martin (Cam.germ., 133) - St. Martin (Cam.rom., 78).

Dintre cele șase cazuri, numai o singură dată numele din original este preluat întocmai (St. Martin - St. Martin). În celelalte cazuri, forma numelui, deși redată în limba română cu alfabet latin, ca în sursă, este modificată, astfel: prin înlocuirea lui $k$ cu $c$ (Porto Rico,Dominica; a se vedea și segmentarea diferită în cazul oiconimului Porto Rico $\sigma^{6}$ ); prin înlocuirea consoanei sonore $g$ prin varianta sa surdă (Antiqua, Kuadelupe; în cazul Antiqua, probabil că a jucat un rol și apropierea mai mare de forma latină), deși pronunția din original nu justifică această înlocuire (cf. MülLERS, s.v.); Mari este încadrat în categoria femininelor în -a (cf. fr. Marie-Galante, sp. Marigalante). Așadar, deși textul-sursă și textul-țintă folosesc același alfabet, procedeele de transfer sînt, în cele mai multe cazuri, transcrierea, adaptarea fonetică și adaptarea morfologică.

În grupajul (2), numele proprii preluate cu alfabet latin din original sînt dublate de forma lor chirilică:

(2) Portosanto (Cam.germ., 11) - Порто Gánтo, Porto Santo (Cam.rom., 9),

Madeira (Cam.germ., 11) - MaAeípa, Madeira (Cam.rom., 9),

Quibio (Cam.germ., 244) - Kwibio, Кви́вї (Cam.rom., 162),

St. Domingo (Cam.germ., 256) - St. Domingo, Gа́nт Аоми́мго (Cam.rom., 172, 185, 187), die Stadt Nombre de Dios (Cam.germ., 237) - cetatea Nombre de Dios ${ }^{7}$, Nomspe ae дïo (Cam. rom., 158).

De data aceasta, forma cu alfabet latin este preluată prin imitație aproximativă, cu excepția lui Kwibio, cf. germ. Quibio, caz în care procedeul de transfer este transcrierea (vezi din nou segmentarea diferită pentru Porto Santo). Forma chirilică a numelor o transliterează pe cea cu alfabet latin din textul românesc.

Grupajul (3) prezintă mai multe tipuri de situaţii:

${ }^{6}$ Numele îi erau, probabil, cunoscute învățatului în forma lor din limba spaniolă.

${ }^{7}$ Scris Dioe, probabil dintr-o eroare de tipar. 
(3) das Vorgebirge derguten Hoffnung (Cam.germ., 12) - munților de Bona Speranza, в8̈ней мъА К̈жає (Cam.rom., 9),

den Namen Trinidad (Dreieinigkeit) (Cam.germ., 179) - Trinidat (adecă Трои́цъ) (Cam.rom., 114),

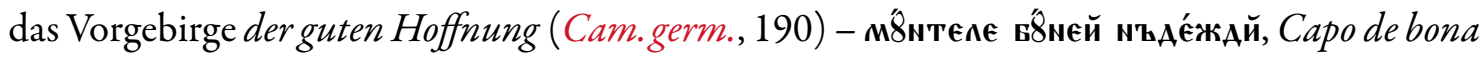
Speranza (Cam.rom., 123),

Gracias a Dios, oder Gott sei Dank (Cam.germ., 230) - numi acest munte: Gratias a Dios, care

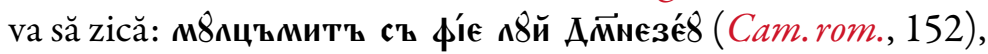

Porto bello (Cam.germ., 237) - Porto bello, adecă Хима́n фр8ммóc (Cam.rom., 158).

Numele proprii scrise cu alfabet latin reprezintă fie împrumuturi din original (Porto bello), fie substituiri (munților de Bona Speranza, Capo de bona Speranza), fie transcrieri (Trinidat, cf. germ. Trinidad, conform regulii germane prin care $d$ final se pronunță surd); la acestea se adaugă latinizarea din Gratias a Dios, cf. Gracias a Dios. Grafia chirilică este utilizată atunci cînd numele este dublat prin traducere: „Trinidat (adecă Трои́цъ)”, „Gratias a Dios, care va să zică: м8пцъммитъ съ фіє п8й Аммнєзе́8”, „Porto bello, adecă Лима́n фр8вмóc".

\subsection{Transliterarea}

Transliterarea este procedeul prin care grafia din limba-țintă este reprodusă în limba-sursă în mod fidel, astfel încît fiecărui semn din alfabetul limbii-țintă îi corespunde unul din alfabetul limbii-sursă (vezi Elman, 1986, p. 29; Grass, 2002, p. 662-663). Firește că focalizarea pe nivelul grafic va duce la un dezechilibru la nivel fonetic.

În perioada premodernă a culturii române, utilizarea transliterării ca procedeu de transpunere a numelor proprii dintr-o altă limbă în limba română implică probleme legate de dificultăţile generale de utilizare a alfabetului chirilic. Ele provin din faptul că acest alfabet nu este compatibil în toate punctele cu structura fonetică a limbii române, ceea ce implică prezența unor slove cu valori multiple ( $\mathbf{k}, \mathbf{b}, \mathbf{v}, \mathbf{k}, \mathbf{A})$, faptul că același fonem poate fi notat prin mai multe slove (cu aceeași valoare fonetică: /e/ prin $\mathbf{k}, \mathbf{\epsilon}, \mathbf{A} ; / \mathrm{i} / \mathrm{prin} \mathbf{v}$, и, ï etc.) sau existența unor slove lipsite de valoare fonetică în anumite cazuri (. sau $\mathbf{~}$ ); problemele sînt amplificate de lipsa unor norme generale de utilizare a alfabetului chirilic, ceea ce face ca fiecare autor să poată inova în limitele sistemului grafic.

Una dintre problemele care apar în cazul transliterării din alfabet latin în alfabet chirilic se referă la numărul diferit de grafeme ale alfabetului chirilic față de cel latin. Aceasta înseamnă că traducătorul poate, în anumite cazuri, să aleagă dintre semnele pe care alfabetul chirilic i le pune la dispoziție. În acest caz, este pusă sub semnul întrebării chiar definiția acestui procedeu, din moment ce același semn grafic latin poate fi şi este transpus în mai multe moduri în alfabet chirilic. Transliterarea propriu-zisă nu poate să vizeze decît acele cazuri de echivalare 1:1, într-un sens sau în celălalt, care sînt foarte puține; în celelalte cazuri, putem vorbi de transliterare aproximativă sau de variante de transliterare. Sakhno (2006, p.711), analizînd transcrierea și transliterarea cu alfabet latin a numelor proprii rusești contemporane ${ }^{8}$, arată că transliterarea nu este întotdeauna exactă (dincolo de faptul că este adesea combinată cu transcrierea în cazul aceluiași nume) și delimitează transliterarea exactă (semnele chirilice fără echivalent direct în alfabet latin sînt redate cu ajutorul diacriticelor; de exemplu, Gorbačêv) de transliterarea aproximativă (cînd diacriticele sînt omise, de exemplu, Gorbacev). De asemenea, Bagajewa (1993, p. 350-351) remarcă inconsistența transliterării și dificultățile pe care le ridică inclusiv împrumutul exact al numelor proprii între limbi care folosesc același alfabet (probleme fonetice cauzate de regulile de ortografie diferite) ${ }^{9}$. Așadar, dacă această problemă caracterizează situația din limba actuală, cu atît mai mult ea constituie o caracteristică a textelor din epoca premodernă românească. Din această cauză, luăm în considerare drept cazuri de transliterare

\footnotetext{
${ }^{8}$ Baza de date pentru selecția corpusului său este internetul.

${ }^{9}$ Vezi şi concluziile lui Lehrer (1993, p. 400) despre imposibilitatea de a construi un algoritm de traducere a numelor proprii.
} 
și situațiile în care suprapunerea nu este totală (intervin diferențe grafice), cu condiția ca acestea să nu afecteze pronunția.

O altă problemă în privința identificării cazurilor de transliterare este cea a accentului. În textele-sursă analizate accentul nu este notat (4); dicționarele onomastice ale epocii nu-l marchează nici ele întotdeauna (numele de persoană sînt foarte slab reprezentate la nivel lexicografic), astfel încît este greu de stabilit dacă accentul din textul românesc corespunde celui din original. Exemplele de mai jos (4) indică situații de utilizare a transliterării în adaptarea numelor proprii de locuri din textele-suport:

(4) Portugal (Cam.germ., 10) - Порт8гі́n (Cam.rom., 8),

Attica (Mil.germ., 11) - Пттика (Mil.rom., XXII $\left.{ }^{10}\right)$,

Kasan (Rum.germ., 46) - Kacan (Rum.rom., 43),

Hannover (Rum.germ., 78) - Ханмовер (Rum.rom., 68),

Niemen (Rum.germ., 81) - Niémen (Rum.rom., 71).

În ultimele trei exemple, alegerea transliterării ca modalitate de redare a numelui propriu în română implică pronunții diferite în limba-țintă față de original: $s$ intervocalic $=/ \mathrm{z} /($ Kasan $) ;-e r$ final $=/ \mathrm{a} /($ Hannover); grupul grafic -ie-(Niemen) se pronunță, în germană, ca un $i$ lung.

În ceea ce privește marcarea numelor proprii prin majusculă, menționăm că, în epocă, aceasta era folosită atît în cazul numelor proprii, cît și pentru alte cuvinte. Fiecare text are particularitățile sale, astfel:

a) în Cam.rom., majuscula marchează numele proprii, mai rar și alte cuvinte (e.g. Căpetenia, Cam. rom., 8; Gheografia, 10; Observații, 13; Crocodilu, 47);

b) în Mil.rom., majuscula marchează numele proprii în mod consecvent, dar este mult mai des folosită la inițiala altor tipuri de cuvinte decît în celelalte texte (și, după cîte se pare, în mod arbitrar);

c) în Rum.rom., numele proprii sînt scrise cu inițială majusculă; în afară de ele, sînt scrise cu majusculă anumite substantive care desemnează funcții publice și instituții sau care sînt neologisme (e.g. Sisteme, Rum.rom., 11).

\subsection{Transcrierea}

În transcriere, atenția se focalizează nu asupra formei grafice, ci asupra formei fonetice a numelui; ca principiu, aceasta trebuie să redea cît mai fidel pronunția din limba de origine. Principiul fidelităţii față de pronunția din limba-sursă consituie și astăzi ideea de bază în cazul numelor proprii preluate din limbi cu alfabet diferit, deși este, încă, un deziderat de atins; vezi, în acest sens, Sakhno (2006), care discută diferențele apărute în rezultatele transferului numelor rusești prin transliterare şi felul în care acestea trădează principiul fidelității față de pronunție.

În textele studiate, transcrierea fonetică a unui nume propriu poate urmări modelul limbii-sursă (traducătorul reproduce numele aşa cum este pronunțat în limba textului pe care îl traduce) sau un model preexistent (transcrierea în textul românesc nu urmărește pronunția din textul-sursă, ci poate fi conformă unui model preexistent de pronunție a unor litere/grupuri de litere). Transcrierea este deseori combinată cu transliterarea și adaptarea fonetică.

Grupajele de mai jos conțin exemple de transcriere în cazul toponimelor, cu următoarele particularități: ae/ä $=\mathbf{\epsilon}(5 \mathrm{a}) ; z / \mathrm{ts} /=\mathbf{4}(5 \mathrm{~b}) ; c+e, i=\mathbf{4}(5 \mathrm{c}) ; C h=\chi(5 \mathrm{~d}) ; P h=\$(5 \mathrm{e}) ;$ notarea pronunțării surde a consoanei finale din germană $(d=t)$ în grupajul $(5 \mathrm{f})$ :

(5) a. Aethiopien (Mil.germ., 13) - G.ï̈nіïa (Mil.rom., 15), dar (o singură dată) Gтxiönï̀ (Mil. rom., 108), Aegos Potamos (Mil.germ., 265) - Gróc Пота́moc (Mil.rom., 387),

b. Barzelona (Cam.germ., 125) - Барцеко́мa (Cam.rom., 73), Klazomenä (Mil.germ., 282) - Клацоме́ма (Mil.rom., 412),

\footnotetext{
${ }^{10}$ Cuprinsul din Mil. rom. este așezat înainte de textul traducerii propriu-zise, paginile fiind notate cu litere romane.
} 
Zanguebar (Cam.germ., 190) - Цекгвева́р (Cam.rom., 124),

Danzig (Rum.germ., 82) - Аа́мциг (Rum.rom., 73),

c. Lacedämons (Mil.germ., 9) - Мацеаємón8п8й (Mil.rom., XIX),

Decelia (Mil.germ., 259) - Аєце́nïa (Mil.rom., 376),

Sicilien (Mil.germ., 258) - Сици́nїа (Mil.rom., 374),

Phocis (Mil.germ., 247) - Фо́цис (Mil.rom., 358),

Mycenä (Mil.germ., 152) - Мице́ме (Mil.rom., 204),

d. China (Mil.germ., 4) - Хи́мa (Mil.rom., XI), dar Ки́мa (Rum.rom., 73),

Colchis (Mil.germ., 150) - Kónхи́c (Mil.rom., 202),

e. Pheres (Mil.germ., 291) - Ф'épec (Mil.rom., 427),

f. Trinidad (Cam.germ., 181) - Тримида́т (Cam.rom., 115),

Madrid (Cam.germ., 22) - Малри́т (Cam.rom., 17),

g. Dominika (Cam.germ., 132) - Dominica (Cam.rom., 78),

Guadalupe (Cam.germ., 133) - Kuadelupe (Cam.rom., 78),

Antigua (Cam.germ., 133) - Antiqua (Cam.rom., 78),

Quibio (Cam.germ., 244) - „Kwibio, Кви́вї” (Cam.rom., 162).

Traducerea toponimelor se caracterizează printr-un oarecare grad de stabilitate, explicabil prin faptul că sînt, în general, nume cunoscute, cu tradiție. Se constată, totuși, multe ezitări ale traducătorilor, amestecul de procedee și de modele lingvistice, inclusiv în transferul aceluiași nume (e.g. Xи́мa vs Kúwa, sub influența unor modele lingvistice diferite).

Grupul $g u$, care apare în toponime sud-americane/spaniole, este transpus prin кв în limba română: Guadalupe - Kuadelupe, Antigua - Antiqua; cf. și antroponimele Guakanahari (Cam.germ., 155) Квакамаха́ри (Cam.rom., 95), Aguado (Cam.germ., 167) - Яква́Ao (Cam.rom., 104). Totuși, în AnLeITUNG, s.v. se recomandă pronunțarea spaniolă în aceste cazuri (e.g. Guadalquivir/guadalkiwir/; Quito /kito/; dar Quarnero /kwarnáro/ - golf în Marea Adriatică, cf. croat. Kvarner).

În Cam. rom., transcrierile sau transliterările cu caractere chirilice sînt dublate uneori de reproducerea numelui cu alfabet latin (vezi supra, \$3.1); această reproducere în limba română cu alfabet latin nu este o transliterare [vezi $(5 \mathrm{~g})$ ], așa cum ar fi de așteptat, ci o situație bizară de transcriere a pronunției din original ( $q u=k w ; G$ inițial asurzit la $k ; g u=k u)$.

\subsection{Transcrierea prin aproximare fonetică}

Necesitatea aproximării fonetice este determinată de incompatibilitățile dintre sistemele fonetice ale limbilor care intră în contact; confruntat cu un fonem inexistent în limba proprie, traducătorul îl notează aproximativ în limba-țintă. Ne vom referi, așadar, la modificările fonetice care apar în procesul de transcriere.

Aproximările fonetice în textele cu original german (6) vizează două vocale pe care sistemul limbii române nu le are: /y/ (vocala anterioară închisă rotunjită, notată ca ü sau $y$ ) și /E/ (vocala anterioară semideschisă rotunjită, notată ca oe sau $\ddot{o})$ :

(6) Südamerika (Cam.germ., 197) - Зи́д-Яме́рика (Cam.rom., 128),

Brünn (Rum.germ., 80) - Брим (Rum.rom., 70),

Lübeck (Rum.germ., 82) - Пювє́к (Rum.rom., 72),

Hayti (Cam.germ., 88) - Ха8ти́́ (Cam.rom., 49),

Böotien (Mil.germ., 281) - Eє́ślïa (Mil.rom., 411),

Pötidäa (Mil.germ., 246) - Поти́́nea (Mil.rom., 356),

den See Moeris (Mil.germ., 12) - М́́pис (Mil.rom., 13).

În reproducerea acestor vocale, traducătorii oscilează între $\mathbf{n}, \boldsymbol{1}$ și 8 pentru prima (aşadar, între vocale și un diftong: Зи́А-Яме́рика, Хюве́к, Ха8тти́) și între จ și є pentru a doua (Бє́́цїа, Мє́рис). 


\subsection{Un caz aparte de adaptare: substituirea fonetică}

$\mathrm{Nu}$ ne referim aici la substituire ca procedeu de traducere a numelor proprii prin înlocuirea cu un nume alcătuit pe teren românesc și folosit frecvent, de exemplu: Impărăția Turcească pentru Turcia, Crăia Franțuzului pentru Franța, Țara Ungurească/Pămîntul Unguresc pentru Ungaria ${ }^{11}$. Avem în vedere mai degrabă ceea ce Ballard (2011, p. 42-43) numește „asimilare fonetică”, mai exact, un caz special, care derivă din situația aparte pe care o înregistra cultura română în epocă. Terminologia propusă de Ballard, în acest caz, ni se pare improprie, întrucît poate crea confuzii dacă o raportăm la ceea ce reprezintă fenomenul asimilării în fonetică. Ballard se raportează la relația dintre limbile franceză și engleză; pentru el, asimilare fonetică înseamnă variante fonetice distincte pentru franceză/engleză ale aceluiași nume propriu. Vaxelaire (2006, p. 720) numește acest procedeu „adaptare”.

Situaţia din textele discutate aici este ceva mai complicată, din cauză că face să apară în ecuația limbăsursă - limbă-țintă un al treilea idiom. Cultura română se caracterizează, atît în epoca veche, cît și la începutul perioadei premoderne, prin utilizarea unei limbi de cultură, alta decît limba română; pentru epoca veche, aceasta este slavona; în secolul al XVIII-lea, odată cu Epoca Fanariotă, locul slavonei este luat de limba greacă, astfel încît greaca devine efectiv mijloc de vehiculare a culturii în Principatele Române, așa cum în Ardeal limba de cultură este latina. În aceste condiții, adesea, traducătorul alege să nu reproducă prin transcriere pronunţia numelui propriu din original, ci, mai ales cînd acesta este exonim în raport cu limba-sursă, îl înlocuiește cu o variantă a numelui care îi este familiară (și pe care a receptat-o, așa cum arată fonetismul, prin intermediul limbii grecești sau al limbii latine) sau restituie pronunția numelui din limba universului de referință al textului. Într-un alt subtip, traducătorul, atunci cînd transcrie un toponim exotic, pentru care, dată fiind noutatea, nu are un echivalent într-unul dintre sistemele sale lingvistice de referință (româna, greaca, latina), nu reproduce pronunția din limba-sursă, ci îl transcrie conform pronunției pe care forma sa grafică ar avea-o într-una dintre limbile sale de referință.

Așadar, prin substituire fonetică înțelegem înlocuirea pronunției specifice limbii textului-sursă cu una cunoscută și folosită anterior de traducător, sau cu pronunția specifică universului de referință al textului. Grupajul (7) conține exemple de substituiri ale toponimelor (nume proprii cu notorietate) din textulsursă german prin echivalentele lor existente deja în limba română; modelul este pronunţia medievală de tip german a limbii latine $(c i=t, i, c e=t, e)$ :

(7) Cilicie (Mil.fr., 7) - Цили́цїа (Mil.rom., XXI),

Celé-Syrie (Mil.fr., 6) - Целеси́рїа (Mil.rom., XXI),

Damascène (Mil.fr., 23) - Дамасце́ne (Mil.rom., XXI).

În cazul Livland (Rum.germ., 51) - Kи́фпанА (Rum.rom., 48), traducătorul a avut în vedere, în transcriere, modelul rusesc (cf. rus. Аифляндนия). Existența mai multor modele de pronunție este evidentă în grupajul (8):

(8) Cypern (Mil.germ., 282) - Ки́пр8 sau Ци́пр8п (Mil.rom., 412),

Scyros (Mil.germ., 282) - Gци́рос sau Gки́рос (Mil.rom., 412),

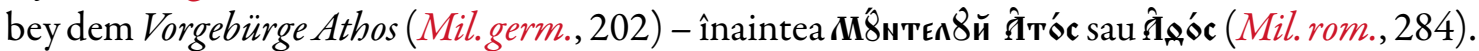

Traducătorul indică el însuşi, explicit, faptul că un anumit nume propriu poate avea pronunții diferite. Diferențele provin sau din raportarea la modele lingvistice diferite, sau, ca în cazul oronimului Athos, din utilizarea unor procedee de transfer diferite (transcriere, respectiv transliterare).

\footnotetext{
${ }^{11}$ Cf. „desemnare distinctă” (Ballard, 2011, p. 54-55) sau „dénomination multiple” (Vaxelaire, 2006, p. 720).
} 


\section{Adaptarea morfologică}

Unele toponime străine au pătruns în limba română prin intermediul mai multor limbi (greacă, italiană, franceză, germană etc.), primind, astfel, forme diverse. Altele au fost substituite cu corespondentele (formale sau denominative) lor românești, consacrate prin tradiție $(9)^{12}$, așa cum este situația și în traducerile pe care le studiem:

(9) Aegypten (Cam.germ., 13) - Eghipet (Cam.rom., 10), von Genua (Cam.germ., 20) - Ghénovii (Cam.rom., 15), Venedig (Cam.germ., 15) - Venéția (Cam.rom., 11), Frankreich (Cam.germ., 152) - Fránța (Cam.rom., 92);

Deutschland (Mil.germ., 115) - Ghermánia (Mil.rom., 157), Theben (Mil.germ., 279) - Thévi i3 (Mil.rom., 408);

Russland (Rum.germ., 6) - Rósia (Rum.rom., 7) sau Țeara Rusască (Rum.rom., 3), England (Rum.germ., 6) - Ánglia (Rum.rom., 7), Moskau (Rum.germ., 28) - Móscva ${ }^{14}$ (Rum.rom., 26), Deutschland (Rum.germ., 81) - Țara Nemțească (Rum.rom., 71), Frankreich (Rum.germ., 84) - Fránția (Rum.rom., 74) etc.

În lipsa unor corpusuri de nume proprii anterioare perioadei pe care o studiem, în anumite cazuri este dificil însă de determinat dacă o anumită formă este stabilită de traducător pe baza sursei pe care o traduce sau dacă este impusă de tradiție.

\subsection{Incadrarea în categoria gramaticală a genului}

Pe baza unui corpus de toponime extras din cîteva texte din a doua jumătate a secolului al XIX-lea, IchimTomescu (1978) discută modalitatea adaptării oiconimelor străine în limba română. Conform tipologiei pe care o propune (p. 238), terminațiile toponimice specifice pentru seriile de gen specifice limbii române sînt: a) $-a$, cu variantele -(i) a și -(e) $a$, pentru feminin; b) $-u$ și consoană, pentru non-feminin (masculin); c) terminațiile $-e$ și $-i$, de origine străină, precum și terminația $-o$, improprie sistemului toponimic românesc, nu sînt specifice pentru stabilirea genului gramatical în limba română și ridică mai multe probleme în privința adaptării lor.

Încadrarea toponimelor străine din textele studiate în genurile specifice limbii române este determinată de factori lingvistici (de exemplu, terminațiile toponimice specifice limbii române și cele specifice limbii din care se traduce, gradul de familiaritate cu limba textului tradus) și extralingvistici (e.g. formația culturală a traducătorului, modelul cultural predominant). În funcție de acești factori, traducătorii adoptă o anumită strategie de transpunere a terminației din original în limba română (substituire, transliterare sau adaptare a terminației).

a) În privința horonimelor, se substituie formele în -en cu cele românești în -ia, de exemplu: Brasilien - Brazilia; Spanien - Spánia; Italien - Itália; Indien (Mil.germ., 13) - India (Mil.rom., 15); Persien (Mil.germ., 17) - Persia (Mil.rom., 20); Assyrien, Syrien (Mil.germ., 74) - Assiria, Siria (Mil.rom., 103); Sardinien, Andalusien (Mil.germ., 79) - Sardinia, Andaluzia (Mil.rom., 108); Medien (Mil. germ., 97) - Média (Mil.rom., 129); Gallien (Mil.germ., 124) - Gállia (Mil.rom., 171); Ionien (Mil. germ., 165) - Ionia (Mil.rom., 224). Păstrarea geminatelor arată faptul că traducătorul nu a apelat la o formă deja adaptată, ci a atașat terminația românească -ia la radicalul toponimului din original. De altfel, terminația -ia a fost adăugată adesea pronunției germane a numelui, de exemplu: Sicilien (Mil. germ., 12) - Sițília (Mil.rom., 14), Phönicien (Mil.germ., 83) - Fenițía (Mil.rom., 115), Bäotien (Mil.germ., 219) - Beóția (Mil.rom., 313), Macedonien (Mil.germ., 245) - Mațedónia (Mil.rom., $354)$.

\footnotetext{
${ }^{12}$ Cf. „numirile tradiționale, cu formă românească (Londra, Viena etc.)” (Ștefănescu, 1957, p. 76).

${ }^{13} \mathrm{Cf}$. gr. $\Theta \tilde{\eta} \beta$ al.

${ }^{14}$ Sau de la Moskwa (Rum.germ., 86), care apare în alte contexte din sursa germană.
} 
b) Oiconimele și horonimele în - a sînt păstrate de obicei cu această terminație (specifică și sistemului toponimic românesc), de exemplu: Barzelona (Cam.germ., 125) - Barțelóna (Cam.rom., 73), Madeira (Cam.germ., 16) - Madeira (Cam.rom., 12), Jamaika (Cam.germ., 145) - Iamaica (Cam. rom., 87), Sparta (Mil.germ., 10) - Spárta (Mil.rom., XXI). Toponimul Mycenä15 (Mil.germ., 152), redat în pronunție germană (Mițéne, Mil.rom., 204), primește terminația -e, improprie sistemului toponimic românesc.

c) Unele toponime în consoană primesc terminația feminină -a: Athen (Mil.germ., 8) - Athina (Mil. rom., XVII), Syracus (Mil.germ., 14) - Siracúsa (Mil.rom., XXVIII), Rom (Mil.germ., 25) - Róma (Mil.rom., 32) etc.; altele, în schimb, nu: Salamin (Mil.germ., 12) - Salamin (Mil.rom., XXIV).

d) În Cam.rom. sînt conservate de regulă terminațiile $-e,-i$ și $-o(10)$. De asemenea, sînt păstrate terminațiile consonantice din original (11):

(10) Oronoko (Cam.germ., 182) - Oranóco (Cam.rom., 116), cf. Oranócului (114),

Tejostrom (Cam.germ., 121) - rîul Teio (Cam.rom., 70),

Mexico (Cam.germ., 227) - México (Cam.rom., 150),

Charthago (Mil.germ., 367) - Cartágo (Mil.rom., 253),

Kowno (Rum.germ., 57) - Cóvno (Rum.rom., 54),

Borodino (Rum.germ., 85) - Borodino (Rum.rom., 76),

Guanahani (Cam.germ., 76) - Cvanáhani (Cam.rom., 41),

Hayti (Cam.germ., 88) - Hautí (Cam.rom., 49),

Guadalupe (Cam.germ., 133) - Kuadelupe ${ }^{16}$ (Cam.rom., 78),

Ninive (Mil.germ., 63) - Ninive (Mil.rom., 84),

Mycale (Mil.germ., 221) - Micále (Mil.rom., 312),

(11) zu Lissabon (Cam.germ., 14) - la Lisavón (Cam.rom., 11),

Madrit (Cam.germ., 22) - Madrit (Cam.rom., 17).

În alte texte, terminația $-e$ din limba germană este înlocuită uneori cu cea românească $(-a)$, de exemplu Mytylene (Mil.germ., 264) - Mitiléna (Mil.rom., 384). Terminația de genul feminin -a

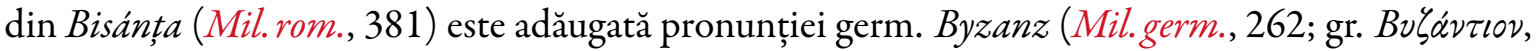
colonie grecească în Antichitate), probabil din nevoia de a îl articula după un alt toponim articulat, raportîndu-l, totodată, la genul categoriei de obiecte („cetate”) din care face parte: „Helespóntul, Bisánţa și alte cetăți le supune puterii Athínii” (Mil.rom., 381), cf. „und brachte der Hellespont, Byzanz, und viele Städte unter die Gewalt Athen” (Mil.germ., 262). Toponimul Byzanz apare și cu terminația -ia: „Hiós, Cós, Ródus și Bizánția să împărechează asupra Athínei” (Mil.rom., 434), cf. "Chio, Cos, Rhodus und Byzanz" (Mil.germ., 296).

e) Ioan Molnar Piuariu, cunoscător de latină, maghiară și germană, păstrează în traducerea sa terminațiile de origine latină și greacă, frecvente în textele sursele germane: Tyrus (Mil.germ., 82) - Tírus (Mil.rom., 112), „Stadt Byblos” (Mil.germ., 82) - „cetatea Biblos” (Mil.rom., 113), Ganges (Mil. germ., 128) - Gánghes (Mil.rom., 176), Delphos (Mil.germ., 200) - Délfos (Mil.rom., 149), Chersones (Mil.germ., 206) - Hersonés (Mil.rom., 290), Eleusis (Mil.germ., 159) - Eleúsis (Mil.rom., 214), Artemisium (Mil.germ., 215) - Artemisium (Mil.rom., 307). Toponimele cu formă latinească sau grecească sînt rareori substituite cu formele românești existente, de exemplu: Damascus (Mil.germ., 74) - Damásc (Mil.rom., 103).

\subsubsection{Opozițiile de gen}

Stabilirea genului depinde atît de terminația numelui propriu din textul-sursă (care variază deseori), cît şi de modalitatea de adaptare: păstrarea formei din original, adaptarea terminației potrivit sistemului

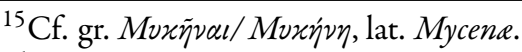

${ }^{16}$ Scris cu grafie latină.
} 
toponimic românesc sau redarea pronunției. Același toponim capătă uneori terminații diferite (feminin, non-feminin/masculin şi nespecifice), constituindu-se, astfel, opoziții de gen, ilustrate în grupajul $(12)^{17}$ :

(12) Cipru

der Insel Cypern (Mil.germ., 235, cf. 73) - ostrovul Chiprul (Mil.rom., 339),

in Cypern (Mil.rom., 297) - în Țípria (Mil.rom., 435),

Cipro (Buf.it., 377) - Chipru (Buf.rom., 22);

Lacedemonia

zu Lacedämon (Mil.germ., 240) - în Lațedemón (Mil.rom., 339),

Lacedämons (Mil.germ., 9) - Lațedemónului (Mil.rom., XIX),

Lacedemone (Buf.it., 375) - Lachedemónie (Buf.rom., 21);

Mexic

Mexico (Cam.germ., 227; Mil.germ., 37) - México (Cam.rom., 150; Mil.rom., 53),

il Golfo del Messico (Buf.it., 434) - colful Mésicu (Buf.rom., 152), Mesic (Buf.rom., 156),

Mexique (Dor.fr., 315) - Mexica (Dor.rom., II, $38^{\mathrm{v}}$ ).

Terminaţia toponimelor din traducerile românești este influențată de cea din textul-sursă; în funcție de aceasta se creează diferite variante formale de gen, de exemplu: Chiprul (masculin) - Țipria (feminin); Mexico (terminație de gen nespecifică limbii române) - Mexica (feminin) - Mesic (masculin).

\subsection{Numărul}

În Mil.rom., forma nesonimelor reflectă modelul german (insulă/ostrov + determinant adjectival provenit de la numele insulei), de exemplu: „mariannischen Inseln” (Mil.germ., 36) - „ostroavele Marianicești” (Mil.rom., 52), „Kanarischen Inseln” (Cam.germ., 16) - „ostroavile Canaricești” (Cam.rom., 12), „Azorischen Inseln” (Cam.germ., 18) - „ostroavelor Azoricești” (Cam.rom., 14); această modalitate de denominare este utilizată uneori și în situația în care forma din original nu este alcătuită cu un determinant adjectival, de exemplu: „Küsten der Azoren” (Cam.germ., 19) - „țărmurile Azoricești” (Cam.rom., 14), nu "țărmurile *Azorelor”.

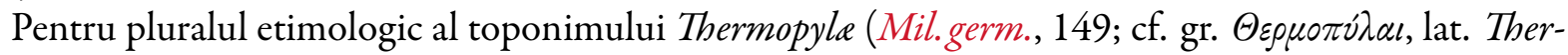
mopyle, „Porțile fierbinți”), se înregistrează singularul Termopila (Mil.rom., 200); forma Termopile (Mil. rom., 302) redă în transcriere pronunția germană a toponimului Thermopylä (Mil.germ., 213).

\subsection{Flexiunea cazuală}

Încadrarea toponimelor străine în seriile de gen și număr specifice limbii române determină formele flexiunii cazuale a acestora (Ichim-Tomescu, 1978, p. 239; Tomescu, 1998, p. 204; Tomescu, 2008). Probleme mai deosebite ridică formele oblice.

a) Toponimele încadrate în seria formelor non-feminine (terminate în consoană și -u) și cele cu terminații nespecifice (în -o) realizează formele oblice sintetic, prin atașarea morfemului masculin enclitic -lui, de exemplu: „curgerea Oranócului” (Cam.rom., 115), „craiului Tírului” (Mil.rom., 112), „limanul Piréiului" (Mil.rom., 322). Morfemul enclitic de genitiv este adăugat uneori după terminația latinească: „marea Mediterranéumului” (Mil.rom., 109); „Die Festungswerke des Piräeus” (Mil. germ., 266) - „întăririle cetății Pireúsului” (Mil.rom., 388), dar „limanul Piréiului” (Mil.rom., 322), traducere care nu redă adjectivul din originalul german: „piräeische Hafen” (Mil.germ., 224).

\footnotetext{
${ }^{17}$ Pentru o imagine mai cuprinzătoare cu privire la opozițiile de gen, am urmărit și formele din alte traduceri din epocă (Buf. rom. și Dor.rom.).
} 
b) Toponimele cu terminația $-a\left(\mathrm{sau}-i a^{18}\right)$, încadrate în seria de gen a numelor feminine, realizează cazurile oblice prin morfemele enclitice $-e i s ̦ i-i i /-i^{19}$, aflate în variație liberă în textele studiate, de exemplu:

Cam.rom.: „aceasta e harta Américei” (Cam.rom., 4), „harta Américii” (Cam.rom., 41), „, tărmurile Áfricei” (Cam.rom., 12, cf. 112, 123), "partea de sus a Africii” (Cam.rom., 17, cf. 123), „vistieria Spániei” (Cam.rom., 26), „Craiul Englitérii” (Cam.rom., 92) etc.;

Mil.rom.: Troadei (Mil.rom., 108), „dă războiu Sțitiei sau Schiftii, și Colbisii și Tráții” (Mil.rom., 15), „mai-marele cetății Médiei” (Mil.rom., 127), „featii craiului Médii” (Mil.rom., 133), „dătătoriul de leage al Athinii” (Mil.rom., 263), ,asupra Siracúzii” (Mil.rom., 368) etc.;

Rum.rom.: „Craiul Ángliei” (Rum.rom., 7), „Craiul Sardiniei” (Rum.rom., 68), „împăratul Aústriei” (Rum.rom., 70), „ceale dinlăuntru ale Rósiei” (Rum.rom., 75, glosă), „se cuvine Róssiei acea laudă” (Rum.rom., 78) etc.; în acest text, flectivul de genitiv-dativ -ei este predominant.

c) În textele analizate, toponimele cu terminațiile -ca sau - ga exprimă cazurile oblice prin morfemele enclitice $-e i s ̧ i-i i$, aflate în variație liberă în acelaşi text sau de la un text la altul, de exemplu: „aceasta e harta Américei” (Cam.rom., 4), "harta Américii” (Cam.rom., 41), "țărmurile Áfricei” (Cam.rom., 12, cf. 112, 123), „partea de sus a Áfricii” (Cam.rom., 17, cf. 123); „părțile Afrícii” (Mil. rom., 109).

d) Uneori, derivatele adjectivale etnonimice din originalul german sînt transpuse în limba română prin horonimul corespunzător precedat de prepoziție, cu valoare de genitiv, de exemplu: „die indianischen Güter” (Cam.germ., 14) - „mărfurile de India” (Cam.rom., 12).

\section{Concluzii}

O caracteristică a traducerii toponimelor din textele studiate este o s c i l a ț i a, atît în ceea ce privește alegerea procedeului de traducere/transfer, cît și în ceea ce privește rezultatul. Alegerea modalității de transpunere în limba română depinde de mai mulți factori, unii lingvistici (incompatibilităţile între sistemele grafice și fonetice, precum şi între principiile care guvernează ortografia limbilor aflate în contact; existența, în cazul numelor proprii foarte cunoscute, a unor modele tradiționale de pronunție), alții care țin de textul tradus (conținutul textului, tipurile de nume proprii pe care le cuprinde) sau de personalitatea traducătorului (cunoștințele lingvistice, formația culturală, opiniile lingvistice). Același toponim (inclusiv cele notorii) cunoaște mai multe modalități de transfer, cu rezultate multiple, nu doar de la un text la altul, ci chiar în interiorul aceluiaşi text. Uneori, traducătorul însuşi (vezi Mil.rom.) indică în text, în mod explicit, existența mai multor posibilităţi de transpunere în limba română.

În privința a d a p tă r i i g r a fi c e și fo n e t i c e, procedeul de traducere cel mai utilizat este transcrierea. Există două situații: a) transcrierea urmărește să reproducă pronunția numelui propriu în limba-sursă; b) traducătorul încearcă să reproducă prin transcriere pronunția dintr-o limbă terță (mai ales în cazul toponimelor care sînt exonime în raport cu limba-sursă). În general, în epocă, limba terță putea fi una dintre limbile de cultură ale vremii, cu care traducătorii erau familiarizați (în textele discutate aici, limba latină, în pronunție medievală), sau limba universului de referință al textului (de exemplu, rusă pentru Rum.rom., care vorbește despre realități ale Imperiului Rus). Dată fiind lipsa de suprapunere dintre sistemele fonetice ale limbilor aflate în contact în traducere, traducătorii operează uneori aproximări fonetice, încercînd să reproducă fonemul care lipsește din sistemul limbii române printr-unul pe care limba română îl posedă.

Referitor la a d a p ta re a m or folog i că, încadrarea într-o serie de gen a unui nume propriu este influențată de terminația acestuia din limba textului-sursă (adesea fluctuantă) și de procedeul de traducere adoptat. Astfel, terminațiile din limba sursă pot fi: a) menținute (prin tra n sli t e r a r e) sau îndepărtate

\footnotetext{
${ }^{18}$ Spre deosebire de textele cu surse occidentale, care se înscriu în modelul de accentuare latinesc, textele cu original grecesc, sub influența sursei, păstrează cazuri de accentuare pe ultima silabă $(-i a)$.

${ }^{19}$ După Coteanu (1969, p. 119), flectivul -i este „o grafie a lui -ii”; vezi și Diaconescu (1970, p. 208), după care - $i$ reprezintă rezultatul contragerii encliticului $-i$.
} 
(rezultînd, de regulă, o terminație consonantică); b) s u b s t i t u i t e cu unele specifice sistemului denominativ al limbii române (de exemplu, horonimele germane în -en substituite cu cele românești în -ia); c) a dapt a te (de regulă, prin transcrierea pronunției). Diversitatea strategiilor de adaptare a terminațiilor şi căile multiple (diferite limbi) de pătrundere a unui toponim străin în limba română duc, în anumite cazuri, la constituirea opozițiilor de gen; acestea se reflectă, ulterior, într-un model sau altul de flexiune cazuală. Referitor la particularităţile flexiunii cazuale, în textele analizate, flectivele de genitiv-dativ -ei și -ii se află în variație liberă.

\section{Bibliografie}

\section{A. Surse}

Buf. it. $=$ [Claude Buffier], Geografia universale del P<adre $>$ Buffier, Edizione prima Romana aumentata, corretta e ridotta in miglior forma, con un nuovo Trattato della Sfera e d'una Dissertazione sopra l'origine e progresso della Geografia, dal $\mathrm{P}<\mathrm{adre>}$ Francesco Jacquier, in Roma, a spese di Venanzio Monaldini, mercante di Libri, 1775.

Buf.rom. = [Claude Buffier], De obște gheográfie pe limba moldovenească, scoasă de pe Geográfie lui Búfiér după orînduiala care acum mai pre urmă s-au aşăzat în Académie de la Parízi, acum întîi tipăită în zilele Prealuminatului și Preaînălţatului Domnului nostru Alexandru Ioan Calimah V<oie>vod, cu blagosloveniia și cu toată cheltuiala Preaosfințitului Mitropolit a toată Moldáviia, Kirío Kir Iácov, întru a Preosfinției sale Tipográfie, s-au tipărit de ierodiacon Gherásim și de Pável Petrov tipografi), în $\mathrm{Sf}<\hat{i}>$ nta Mitropolie în Iaşi, avgust 22, 1795.

Cam.germ. $=$ [Joachim Heinrich Campe], Kolumbus oder die Entdekkung von Westindien. Ein angenehmes und nützliches Lesebuch für Kinder und junge Leute, von J.H. Campe, mit allerhochst gnädigst Kayserl. Privilegio, Tübingen, bey Wilh. Heinr. Schramm und Joh. Friedr. Balz., 1782.

Cam.rom. = [Joachim Heinrich Campe], Descoperirea Américii. O carte foarte folositoare, alcătuită de Ioánn Háinrih Cámpe, acum întiìu de un iubitoriu de neamul românesc pre românie tălmăcită și dată afară la lumină, tomul I, cu 4 figuri, cu toată chieltuiala lui Nicóla Nicoláu din Braşov, dată în tipariu la Buda, Crăiasca Tipografie a Universitatei din Péșta, 1816.

Dor.fr. $=$ [André Guillaume Contant d'Orville], Histoire des différents peuples du monde, contenant les cérémonies religieuses et civiles, lorigine des religions, leurs Sectes \& Superstitions, \& les Mours \& Usages de chaque Nation, dédiée à monseigneur le Duc de Vrilliere, ministre et secrétaire d'état par M. Contant Dorville, tome cinquième, à Paris, chez Herissant le Fils Libraire, 1771.

Dor. rom. $=[$ André Guillaume Contant d'Orville], Istoria Americăi, cuprinzind un perilipsis a aflării ei, țerimóniiile bisericești și politicești [...], acum întîi tălmăcite în dialectul moldovenesc, prin ostineala smeritului Gherasim, arhimandrit Mitropoliei Iaşului, Iaşi, tomul I (1800), tomul 2 (1795) [în ms. rom. IV-17 BCU-Iaşi].

Mil. fr. $=$ [Claude François Xavier Millot], Éléments d'histoire générale, première partie: Histoire ancienne, par M. l'Abbé Millot de l'Académie Françoise, \& des Académies de Lyon \& Nancy, tome premier, Nouvelle édition augumentée, à Paris, Chez Durand neveu, 1790.

Mil.germ. $=$ [Claude François Xavier Millot], Des Herrn Abt <Claude> Millot, Mitglieds der Akademie zu Lyon, Universalhistorie alter, mittler und neuer Zeiten, aus dem Französischen, mit den Zusätzen von Wilhelm Ernst Christiani, königlich Dänischen wirklichen Justiz - Rath und ordentlichen Professor der Weltweisheit, Beredtsamkeit und Geschichte, wie auch Bibliothekar der königlichen Universität zu Kiel, Erster Band, Bey Franz Haas Buchhändler, Wien, 1794.

Mil.rom. $=$ [Claude Millot], Istorie universală, ádecă de obște, care cuprinde în sine întîmplările veacurilor vechi, întocmită prin signior Mílot, commembru Académii Frîncești din Lyon, iară acum întîia dată tălmăcită în limba românească, tomul I, în Búda s-au tipărit, în Crăiasca Tipografie Orientalicească a Universitatei Péștii, 1800.

Rum.germ. $=$ [Johann Daniel Friedrich Rumpf ], Alexander I, Kaiservon Russland. Ein Regierungs- und Karaktergemälde, von I.D.F. Rumpf, Königl. Preuss. expedir. Secretär bei der Abgaben-Direction in Berlin, bei G. Hayn, mit dem Bildniss des Kaisers, 1814.

Rum.rom. = [Johann Daniel Friedrich Rumpf], Arătarea stăpinirei și a caracterului lui Alexándru I, impăratul a toată Róssia, întocmită prin I.D.F. Rumpf, Crăiescul Praisesc a Direcției din Berlin Secretar-Expedítor și Mărirei Sale celui pre dreptate și moștenitoriu Craiu al Borúsiei Frídrih Vílhelm III închinată, iară acum întîiu pre Românie prefăcută și tipărită la Buda, în Crăiasca Tipografie a Universitatei Ungáriei, 1815.

\section{B. Lucrări de referință}

ANLEITUNG = Anleitung zut richtigen Aussprache geographischer und geschichtlicher Eigennamen, L. Frey'sche Buchhandlung, Ulm, 1863.

Bagajewa, J. (1993). Geographical Names: Problems of Equivalence and Translability, în Lewandowska-Tomaszczuk, B. \& Thelen, M. (eds), Translation and Meaning, vol. II: Proceedings of the Eódź Session of the 1990 Maastricht-Eódź Duo Colloquium on "Translation and Meaning” held in Eódź, Poland, 22-29 September 1990, Rikkhogeschool Maastricht, Maastricht, p. 349-354. 
Ballard, M. (2011). Numele proprii în traducere [Nom propre en traduction, Ophrys, Paris, 2001], traducere, cuvînt înainte și note de Georgiana Lungu-Badea, Editura Universității de Vest, Timișoara.

BERTACCHI = Cosimo Bertacchi, Nuovo dizionario geografico universale, vol. I-II, Unione Tipografico Editrice, Torino, 1904. Bârsan, A. (1961). Considerații asupra scrierii numelor geografice străine, în „Limba română”, vol. 10, nr. 5, p. 415-424.

Boerescu, P. (2014). Din istoria scrierii românești, Editura Academiei Române, București.

Bolocan, Gh. (1961). Despre redarea numelor proprii dintr-o limbă în alta, în „Limba română”, vol. 10, nr. 6, p. $582-587$.

Boutourlin, P. (1874). Les noms propres étrangers. Leur orthographe et leur prononciation, Seconde Édition, Combe et Vande Weghe imprimeurs, Bruxelles.

Cernovodeanu, P. (1974). Préoccupations en matière d'histoire universelle dans l'historiographie roumaine au XVIIe et XVIIIe siècle, în „Revue Roumaine d'Histoire”, vol. 9, nr. 1, p. 73-94.

Coteanu, I. (1969). Morfologia numelui în protoromână (româna comună), Editura Academiei Române, București.

Creția, P. (1958). Numele proprii grecești în românește, în „Limba română”, vol. 7, nr. 2, p. 54-59.

Costa, T. (1958). Numele proprii latinești în românește, în „Limba română”, vol. 7, nr. 4, p. 70-77.

Diaconescu, P. (1970). Structură și evoluție în morfologia substantivului românesc, Editura Academiei Române, București.

Elman, J. (1986). Le problème de la traduction des noms propres, în „Babel”, vol. 32, nr. 1, p. 26-30.

Garde, P. (1974). La transcription des noms propres français en russe, Institut d'Études Slaves, Paris.

Gheție, I. (1975). Baza dialectală a românei literare, Editura Academiei Române, București.

Gheție, I. (1982). Introducere în studiul limbii române literare, Editura Științifică și Enciclopedică, București.

Gheție, I. \& Mareș, Al. (1985). Originile scrisului în limba română, Editura Științifică și Pedagogică, București.

Grass, Th. (2002). Quoi! Vous voulez traduire «Goethe»? - Essai sur la traduction des noms propres allemand-français, Peter Lang, Berne.

Grămadă, L. (1960). „Istoria lui Millot” în tălmăcirea lui Ioan Piuariu Molnar, în „Studia Universitatis Babeș-Bolyai. Philologia”, 4/2, p. 161-175.

Ichim-Tomescu, D. (1978). Observații asupra adaptării morfologice a toponimelor străine în limba română, în „Limba română”, vol. 27 , nr. 3, p. 237-242.

Ivănescu, G. (1980). Istoria limbii române, Editura Junimea, Iași.

Lehrer, A. (1993). Principles and Problems in Translating Proper Names, în Lewandowska-Tomaszczuk, B. \& Thelen, M. (eds), Translation and Meaning, vol. II: Proceedings of the Eódź Session of the 1990 Maastricht-Eódź Duo Colloquium on "Translation and Meaning" beld in Eódź, Poland, 22-29 September 1990, Rikkhogeschool Maastricht, Maastricht, p. 395-402.

Minuț, A.-M. \& Lihaciu, I. (2014). Interpolarea ca strategie de traducere a „Istoriei universale adecă de obște, care cuprinde în sine întâmplările veacurilor vechi”, versiune în limba română de Ioan Piuariu Molnar, în Dima, E. \& Corbea-Hoișie, A. (eds), Impulsul Iluminismului în traduceri românești din secolul al XVIII-lea, Editura Universității „Alexandru Ioan Cuza”, Iași, p. 91-136.

MüLLERS = August Müllers, Allgemeines Wörterbuch der Aussprache ausländischer Eigennamen, Verlag von E. Haberland, Leipzig, 1903.

Munteanu, Șt. \& Țâra, V.D. (1983). Istoria limbii române literare. Privire generală, Editura Didactică și Pedagogică, București.

Nedelcu, I. (2012). Substantivul, în Chivu, Gh. et al. (eds), Studii de istorie a limbii române. Morfosintaxa limbii literare în secolele al XIX-lea și al XX-lea, Editura Academiei Române, București, p. 37-62.

Piru, Al. (1970). Istoria literaturii române. II: Epoca premodernă, Editura Academiei Române, București.

Sakhno, S. (2006). Nom propre en russe: problèmes de traduction, în „Meta”, 51/4, p. 706-718.

Săulescu, Gh. (1833). Grammatică românească sau observații grammaticești asupra limbei românești pentru scoalele normale și ghimnaziale, compusă de Gheorghie Seulescul; partea întîia, Etimologhică, Tipografia Mitropolii, Iașii.

SCHNAKEnBuRg = J. F. Schnakenburg, Orthographisches Wörterbuch der gesammten alteren und neueren Geographie und der Eigennamen der Personen, Verlag von Johann Ambrosius Barth, Leipzig, 1835.

Stan, C. (2012). Ortografia și ortoepia. Secolul al XIX-lea, în Chivu, Gh. et al. (eds), Studii de istorie a limbii române. Morfosintaxa limbii literare în secolele al XIX-lea și al XX-lea, Editura Academiei Române, București, p. 1-28.

Strungaru, D. (1976). Pe marginea interpretării normelor ortografice în recentele ediții a două vechi gramatici românești (Evstatievici și Diaconovici), în „Limba română”, vol. 25, nr. 2, p. 197-204.

Ștefănescu, C.M. (1957). Transcrierea numirilor geografice străine în text românesc, în „Limba română”, vol. 6, nr. 4, p. 76-79.

Theban, L. (1965). Din nou despre transliterarea denumirilor geografice străine, în „Limba română”, vol. 14, nr. 1, p. $139-141$.

Tomescu, D. (1998). Gramatica numelor proprii în limba română, Editura ALL, București.

Tomescu, D. (2008). Substantivele proprii, în Valeria Guțu Romalo (coord.), Institutul de lingvistică „Iorgu Iordan - Al. Rosetti", Gramatica limbii române, vol. I: Cuvântul, Editura Academiei Române, București, p. 118-128.

Ursu, N.A. (2002). Contribuții la istoria culturii românești. Studii și note filologice, Editura Cronica, Iași.

Vaxelaire, J.-L. (2006). Pistes pour une nouvelle approche de la traduction automatique des noms propres, în „Meta”, 51/4, p. 717738. 